\title{
Influence Factors of Users Satisfaction of Mobile Commerce -An Empirical Research in China
}

\author{
Ping-hao YE \\ School of Information Engineering, \\ Wuhan Business University \\ Wuhan City, Hubei Province, China \\ e-mail:yezigege1977@163.com
}

\begin{abstract}
This study establishes a structural model to measure user satisfaction toward mobile commerce (m-commerce) from the perspective of $\mathrm{m}$-commerce participants by analyzing factors influencing user satisfaction. A questionnaire survey on $428 \mathrm{~m}$-commerce users is conducted. The model is verified by regression analysis and other analytical methods, and factors influencing the user satisfaction are determined. The features of $\mathbf{m}$-commerce applications, performances of mobile intelligent terminals, and service quality of m-commerce are key factors influencing user satisfaction.This study proposes suggestions and recommendations to enhance user satisfaction and improve the vitality of $\mathrm{m}$-commerce ecosystem. It further promotes $\mathrm{m}$ commerce among customers, and thus increasing efficiency in learning, living, and working. The conclusions explain the factors influencing user satisfaction and provide recommendations and references for mobile network service providers, smart phone manufacturers, mobile application service providers, and other m-commerce participants to increase their market shares.
\end{abstract}

Keywords -Mobile commerce; User satisfaction; Influence factors; Consumer behavior

\section{I.INTRODUCTION}

With the development and application of $4 \mathrm{G}$ mobile communication technologies, mobile devices can be seamlessly connected to the online stores of vendors, thus promoting the rapid expansion of their mobile stores [1]. A new business service model, that is, mobile commerce (mcommerce), is growing quickly at a global scale. Although mcommerce has been effectively applied in the developed countries such as Japan, South Korea, and the United States, it remains in the initial growth stage in developing countries $[2,3]$. The scale of $\mathrm{m}$-commerce users in China had reached 0.364 billion by the end of 2015 , with an increase of $23.8 \%$, and the number is estimated to approach 0.5 billion in 2018 (China E-Business Research [4]. Investigating the satisfaction of this rapidly growing user group is conducive to the healthy development of the m-commerce market.

The rapid development of m-commerce has strongly influenced the work, learning, and daily life of users [5]. An increasing number of operators have attracted considerable attention among customers by improving customer satisfaction through developing mobile applications, hereafter referred to as apps. User satisfaction lays a foundation for achieving the goals of m-commerce, and it has already become an important issue that vendors face when they apply $\mathrm{m}$-commerce in their business operations. User satisfaction toward $\mathrm{m}$-commerce has become a favored topic among

\author{
Li-qiong LIU \\ School of Information Management, Wuhan University; \\ Wuhan Business University \\ Wuhan City, Hubei Province, China \\ e-mail:quandian7373@163.com
}

experts and scholars at home and abroad. Evaluating user satisfaction toward m-commerce is helpful for understanding user demand

improving the service quality of $\mathrm{m}$-commerce, increasing customer satisfaction, building competitive edges, and attaining long-term profitability. This study investigates business-to-consumer (B2C) m-commerce.

\section{II .LITERATURE REVIEW}

The rapid advancement of wireless communication technology and mobile communication network as well as the growing popularity of mobile devices have created favorable conditions for the development of $\mathrm{m}$-commerce in China. Despite the steadily improving service quality of $\mathrm{m}$ commerce, different users face emerging and innovative types of m-commerce, resulting in substantial variations in user satisfaction. Evaluating user satisfaction and analyzing the factors influencing the results have been prioritized in many studies. Factors influencing user satisfaction have been studied by numerous scholars. In this study, the factors identified in the existing literature have been summarized into m-commerce app performance, mobile device performance, and service quality (Table I).

\section{A. Overview of m-commerce}

With the constantly increasing popularity of mobile phones in China, the types of devices that can access the Internet have gradually shifted from computers to portable wireless terminals. Mobile devices and apps provide many opportunities for retailers to attract new users [6]. The main features in a mobile environment include new services, affordable transmission services, new players, increasing revenues, and a changing role of mobile network operators [7]. Although consumer shopping behaviors and business development models are influenced by the rapid development of m-commerce, no unified concept or definition of $\mathrm{m}$ commerce has been formed locally or internationally. Experts and scholars differ in their interpretations of m-commerce. Nonetheless, the basic contents and meaning of m-commerce are the same. M-commerce requires mobile terminals and wireless network technologies and involves commercial activities. In this study, m-commerce is defined as an ecommerce system and a pattern in which various information exchanges and business activities are implemented by organically integrated mobile communication devices and wireless network technologies. A large body of literature on $\mathrm{m}$-commerce has been published in journals of economics, 
information, and management. [8]. Classified research on 149 papers of m-commerce has centered on the following major points: $\mathrm{m}$-commerce theory and research, mobile middleware, m-commerce applications and cases, wireless user infrastructure, and wireless network infrastructure. User satisfaction has not been analyzed as an independent category.

\section{B. M-commerce adoption}

The success and potential of the mobile Internet market depend on the use of m-commerce; thus, adoption behaviors of m-commerce users are a popular topic of theoretical research. With the increasing number of mobile phone users, various innovative forms of $\mathrm{m}$-commerce are emerging. Significant differences exist in the adoption behaviors of $\mathrm{m}$ commerce users. The rapid development of society, technology, and economy has induced profound changes in the value chain of mobile applications [7]. Adoption behaviors of users toward new technologies and services have also shifted to a new direction. User age is negatively related to the adoption of $\mathrm{m}$-commerce. The frequency of using $\mathrm{m}$ commerce among young users is higher than that among older users. Young users pay more attention to the convenience of $\mathrm{m}$-commerce [9]. Educational level is positively associated with the use of m-commerce. The higher the

Educational level, the more frequently the user uses location-based $\mathrm{m}$-commerce and transaction services $[10,11]$.

Perceived usefulness, ease-of-use, and pleasure; trust; and network greatly influence the adoption of m-commerce [1117]. Consumer innovativeness, past adoption behavior, and technology cluster adoption may affect the adoption behaviors of $\mathrm{m}$-commerce consumers [11]. Convenience as well as perceived quality and usefulness influence the adoption of m-commerce users [9]. Trust has become an important research topic because it is a key factor influencing user satisfaction [18, 19]. Security, system design, and transaction details are also key factors influencing user trust toward m-commerce [20]. Design aesthetics is a key factor influencing $\mathrm{m}$-commerce websites; it exerts an especially strong influence on perceived usefulness and ease-of-use, thus explaining user trust $[21,22]$. In addition, mobility and information quality reflect the main features of m-commerce, affecting the initial trust of users toward $\mathrm{m}$-commerce [23].

Most current studies on the user adoption of m-commerce are based on the perspectives of technology or social psychology and consumers. Related theories mainly include theory of reasoned action, theory of planned behavior, the technology acceptance model and its extended model, unified theory of acceptance and use of technology, innovation diffusion theory, and task-technology fit. Most studies have focused only on several aspects of the aforementioned factors influencing the adoption behaviors of users. Few studies have combined those at individual, organizational, or national level. The adoption and generalization of $\mathrm{m}$-commerce is classified as system engineering, whose influencing factors contain micro-, enterprise-, industry-, and macro-level information. Studying the factors influencing the adoption of m-commerce based on social psychology from a common user perspective is unbalanced. Creating a new theoretical framework for future studies is necessary, as is considering the individual, organizational, and national levels.

\section{M-commerce satisfaction}

On the basis of studies on factors influencing user satisfaction, the service quality of m-commerce can be improved, enhance user satisfaction, provide a safer and more enjoyable shopping experience, and offer greater benefits to operators. Trust in m-commerce, involvement, and innovativeness have positive effects on user satisfaction [24]. Wireless communication technologies with higher flexibility and mobility provide m-commerce users with great convenience anywhere or anytime, but they are accompanied with security vulnerabilities [25]. Security problems and privacy risks are of primary concern in $\mathrm{m}$-commerce, and the perceived security of $\mathrm{m}$-commerce of Chinese users significantly affects use intention, satisfaction, and loyalty to m-commerce [26]. Word-of-mouth is also a determining factor of user satisfaction [27]. User satisfaction, habits, trust, and perceived value directly affect their loyalty [28]. User loyalty refers to the tendency of customers to purchase commodities and services repeatedly and with stable emotions despite varying environmental effects and changing promotion methods [29]. Individualized innovation affects user intention to continue using m-commerce [30]. Cultivating user loyalty is a perennial concern of $\mathrm{m}$ commerce in spite of rapid changes in information technology.

User satisfaction refers to a user's mental state and selfawareness. Quantifying user satisfaction with accurate indicators is difficult because of its fuzziness and comprehensiveness. Furthermore, measuring user satisfaction is also affected by many factors, including numerous known and unknown information. Such study is especially volatile given that $\mathrm{m}$-commerce remains an unknown concept from a cognitive perspective. 
TABLE I. CUSTOMER SATISFACTION FACTORS OF M-COMMERCE IN THE PREVIOUS STUDIES

\begin{tabular}{|l|l|l|}
\hline Constructs & \multicolumn{1}{|c|}{ Items } & \multicolumn{1}{c|}{ References } \\
\hline $\begin{array}{l}\text { M-commerce App } \\
\text { performance }\end{array}$ & $\begin{array}{l}\text { Transaction process, Content reliability, } \\
\text { Perceived system quality, Convenience of } \\
\text { navigation, Compatibility, Degree of } \\
\text { content quality, Variety of content, design } \\
\text { aesthetics }\end{array}$ & {$[22,31-35]$} \\
\hline $\begin{array}{c}\text { Mobile Device } \\
\text { Performance }\end{array}$ & $\begin{array}{l}\text { Size of image/text, Customization, Brand } \\
\text { image, Brand awareness, Interactivity and } \\
\text { responsiveness, portability, interface } \\
\text { design, speed, search ability, simultaneity, } \\
\text { design aesthetics }\end{array}$ & {$[22,32,35-39]$} \\
\hline Service Quality & $\begin{array}{l}\text { Perceived ease of use, perceived } \\
\text { usefulness ,security, Trust ,Involvement, } \\
\text { Innovativeness, Offline delivery, culture }\end{array}$ & {$[24,26,40,41]$} \\
\hline
\end{tabular}

\section{III.RESEARCH MODEL AND HYPOTHESES}

M-commerce has unique properties compared with traditional e-commerce. The mobility of mobile devices and the universality of mobile networks provide mobile users with the opportunity to use m-commerce anywhere and anytime. Therefore, numerous factors influence customer satisfaction in m-commerce. Consequently, any measurement index system for m-commerce is complex. In this study, a model for measuring user satisfaction is established by combining the characteristics of $\mathrm{m}$-commerce users and the actual market situation of m-commerce (Fig. 1).

\section{A. M-commerce app performance}

On the basis of the value chain model of m-commerce, the effective design of the m-commerce system can improve user satisfaction $[42,43]$, trust in the perceived usefulness of the system, and loyalty to the system [43]. The m-commerce market mainly involves consumers, mobile operators, mobile technologies, and mobile services or products. Mobile operators include network providers, content providers, service or product providers, device providers, and third-party service providers. With regard to the trading relationship in the value chain of $\mathrm{m}$-commerce, users interact with mobile operators via mobile networks based on mobile terminal technologies, and mobile operators transport mobile services to user terminals via networks. In the trading process, users may perceive mobile technologies, operators, and mobile services. Given that $\mathrm{m}$-commerce is readily accessible and that personally interacting with operators is impossible for users, and, thus, m-commerce apps serve as a bridge between users and operators. The number, user comments, and accessibility of mobile application stores affect users' choices of apps [44]. Therefore, the availability, ease-of-use, and download fees of m-commerce apps are primary concerns of users. M-commerce apps are key factors influencing user satisfaction. Such apps determine users' continuous use of m- commerce. They are also key issues for developers in promoting and improving $\mathrm{m}$-commerce [45].

The content reliability and transaction procedures of $\mathrm{m}$ commerce significantly affect user satisfaction and loyalty to $\mathrm{m}$-commerce [31]. M-commerce apps also challenge security, and lack of development standards and application make smart mobile devices vulnerable [46]. M-commerce apps and the perceived risks affect users' attitudes toward m-commerce [47]. Web pages provide users' a first impression of an organization. The aesthetic design of web pages determines whether users stay or leave. Web pages with higher aesthetic value are often highly authoritative [48]. The aesthetic level of the visual design of m-commerce apps deeply affects the perceived usefulness and ease-of-use, finally exerting a positive influence on user loyalty to m-commerce [22]. Perceived interactivity and compatibility may affect user intention to download apps [49]. M-commerce apps are bridges between customers and operators in trading. They are also platforms for displaying transaction details. According to user intention to use and behaviors, the following hypothesis is proposed:

H1. The performance of m-commerce apps significantly affects user satisfaction.

\section{B. Mobile device performance}

Mobile intelligent terminals have been widely applied in the trading process of $\mathrm{m}$-commerce, requiring extremely high security. Therefore, security is highly important when using a mobile system [50]. Mobile devices include mobile phones, PDAs, and other accessible wireless mobile terminals. Moreover, customers' skills in using mobile devices appreciably affect their shopping experience as well as their perceived usefulness of such devices. Accordingly, the shopping experience and perceived usefulness affect customer behavioral intentions to adopt m-commerce [51]. Smartphones functionally promote the convenience and 
security of m-commerce through systems such as e-wallet, epay, and multimedia [52]. In m-commerce transactions, mobile intelligent terminals enable users to shop whenever and wherever they like; such options cannot be provided by computer-based e-commerce terminals (CTs). Simplicity and interactivity are two key factors influencing the usefulness of mobile smartphones [53]. In addition to mistrust, mcommerce faces problems regarding mobile smartphones with low-resolution display screens, limited keyboard functions, less memory space, short battery service time, incompatibility with operating systems, and unstable connection. These features negatively affect user satisfaction.

Users' searches for their desired products are limited by the screen sizes of their mobile devices [1]. Extrinsic mobile device performance-simultaneity, speed, and search ability - as well as intrinsic mobile device performanceportability and interface design - exert positive effects on the perceived ease-of-use and convenience of m-commerce, which, in turn, affect user satisfaction [35]. The compliance of mobile intelligent terminals to the design along with design aesthetics majorly influence the perceived usefulness, ease-of-use, and shopping pleasure, finally affecting user loyalty to $\mathrm{m}$-commerce $[22,39]$. Thus, the following hypothesis is proposed:
H2. The performances of mobile intelligent terminals significantly affect user satisfaction.

\section{C.Service quality}

M-commerce is based on wireless communication networks; thus, it is highly vulnerable to attacks and spyware [54]. The perceived security of transaction and payment, and even user satisfaction, may be affected [55]. The service quality of m-commerce affects user loyalty and the perceived ease-of-use, which subsequently affect user satisfaction [40]. Cultural differences exert significant effects on the adoption of m-commerce [41], and promoting service quality according to the consumption habits of users with different cultural backgrounds is necessary. Perceived risks directly affect user behavioral intentions to adopt m-commerce. Costs are also an important indicator in evaluating user adoption of $\mathrm{m}$-commerce [56]. Web designers, service providers, vendors, and application developers must carefully consider user demands, provide better services, and enhance user satisfaction [57]. Aside from the aforementioned factors, offline distribution services, product price, online consulting services, and other variables affect user satisfaction. Thus, the following hypothesis is proposed:

$H 3$. The service quality of m-commerce may significantly affect user satisfaction.

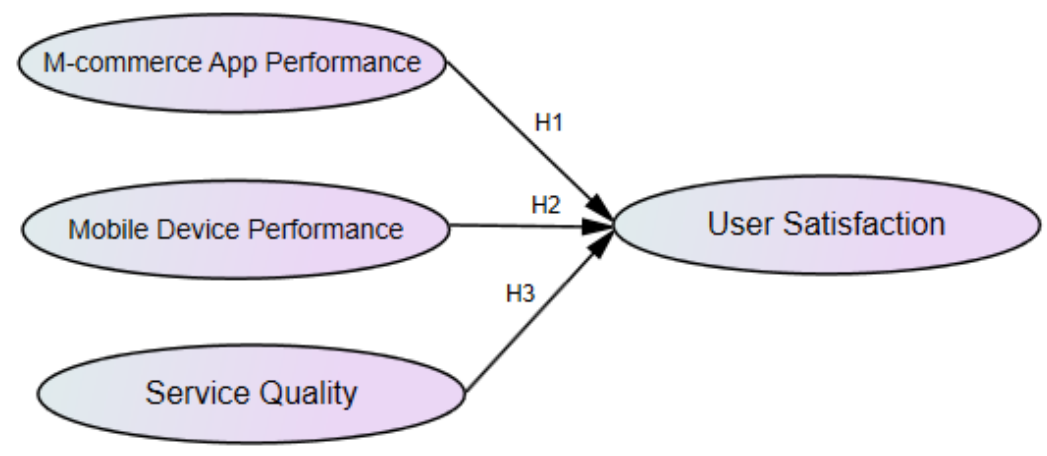

Figure 1. User satisfaction structure model of M-commerce

\section{IV.METHODOLOGY}

\section{A. Sampling and data collection}

The present study adopts questionnaires, with a plurality of indicators for measuring every factor. These indicators are inspired by related literature. To improve the validity of measurement contents, we test the measurement on 50 users experienced in $\mathrm{m}$-commerce before formal data collection. On the basis of their comments, parts of the questionnaires are corrected to enhance readability and intelligibility. Indicators are measured by Likert scale.

Respondents are university students. M-commerce and apps such as location services, mobile games, mobile payment, mobile learning, and mobile shopping are popular among the youth, especially among college students who are the main user group of $\mathrm{m}$-commerce. Thus, choosing college students as respondents is rational. Questionnaires are distributed via online survey platforms. They require students to judge their own experience in mobile reading, mobile social networking, mobile location, mobile shopping, and mobile payment. To conform to the purpose of the present study, these m-commerce apps are selected because of their growing popularity. The collected questionnaires are screened, and those with excessive missing contents are ruled out. Five hundred copies of questionnaires are distributed, but only 428 effective questionnaires are collected.

\section{V.VARIABLE MEASUREMENT}

\section{A. Independent variables}

Variables in the present study are based on previous literature (Table I), and they are used for prediction. They also comprise variables that researchers chose according to their relationship with dependent variables. Combining the roles of m-commerce ecosystem participants, and after consulting experts and scholars, three arguments, namely, m-commerce 
app performance, mobile device performance, and service quality, are determined. Each independent variable is designed to measure three questions whose contents are in conformity. A five-point Likert scale is adopted for measurement (" 1 " is strongly agree, " 2 " is agree, " 3 " is

\section{B. Dependent variable}

The dependent variable is user satisfaction. The independent variables are the predicted variables that researchers use to observe their effect on the dependent variable. Three questions are sorted from the preliminary research results to measure the dependent variable. User satisfaction is measured by a five-point Likert scale ( " 1 " is strongly agree, " 2 " is agree, " 3 " is neutral, " 4 " is disagree, and " 5 " is strongly disagree).

\section{VI.DATA ANALYSIS}

\section{A. Profile of respondents}

Among the respondents, $48.6 \%$ are male, and the rest is female, reflecting the uniform distribution of respondents. neutral, "4" is disagree, and " 5 " is strongly disagree). Nine representative questions are sourced from the previous literature to measure the three variables. Table I presents these factors and the sources of the questions.

The demographic information of respondents is shown in Table II. Among the users, $69.63 \%$ are younger than 20 years old. M-commerce users are younger that non-m-commerce users; $69.39 \%$ of them have college diplomas, which is indicative of having a high educational level. Among the respondents, $76.17 \%$ of them use mobile phones for $\mathrm{m}$ commerce. The portability and Internet accessibility of mobile devices have major influences on the user adoption of m-commerce. Of the respondents, $50.47 \%$ use m-commerce 20 to 30 times per month, indicating that m-commerce has become an important tool in their daily life; $44.16 \%$ of them consider accessibility as a key factor attracting them to mcommerce. Among the users, $42.29 \%$ are fond of the convenience and quickness of m-commerce, and $13.55 \%$ think that the individualized services of $\mathrm{m}$-commerce are attractive.

TABLE II. DEMOGRAPHIC PROFILE OF THE RESPONDENTS

\begin{tabular}{|c|c|c|c|}
\hline Variables & & Frequency & Percent (\%) \\
\hline \multirow[t]{2}{*}{ Gender } & Male & 208 & 48.6 \\
\hline & Female & 220 & 51.4 \\
\hline \multirow[t]{4}{*}{ Age } & $\leq 20$ & 298 & 69.63 \\
\hline & $21-25$ & 76 & 17.76 \\
\hline & $26-30$ & 42 & 9.81 \\
\hline & $\geq 31$ & 12 & 2.8 \\
\hline \multirow[t]{4}{*}{ Education Level } & High school or below & 36 & 8.41 \\
\hline & College & 297 & 69.39 \\
\hline & Undergraduate & 89 & 20.79 \\
\hline & Master or above & 6 & 1.4 \\
\hline \multirow{3}{*}{$\begin{array}{l}\text { Wireless Handheld } \\
\text { Equipment Type }\end{array}$} & Cell Phone & 326 & 76.17 \\
\hline & Laptop & 81 & 18.93 \\
\hline & iPad & 21 & 4.91 \\
\hline \multirow{3}{*}{$\begin{array}{l}\text { Frequency of using } \\
\text { M-commerce }\end{array}$} & 20-30 times a month & 216 & 50.47 \\
\hline & 10-19 times a month & 99 & 23.13 \\
\hline & 1-9 times a month & 113 & 26.4 \\
\hline \multirow{3}{*}{$\begin{array}{l}\text { Advantage of } \\
\text { M-commerce }\end{array}$} & Anytime and anywhere & 189 & 44.16 \\
\hline & Convenient and quick & 181 & 42.29 \\
\hline & Personalized service & 58 & 13.55 \\
\hline
\end{tabular}

\section{B. Scale reliability and factors analysis}

SPSS 22.0 is used to check the reliability of questionnaires. Cronbach a is adopted to check the consistency of questionnaires. After checking, the reliability coefficient of questionnaires is $\mathrm{a}=0.91$, and the reliability of every latent variable is greater than 0.9 . Thus, the reliability of questionnaires is acceptable and consistent with the relevant requirements [58].

Factor analysis aims to extract a small amount of representative independent variables from the originally numerous variables under the condition that the variables are strongly associated. During factor analysis, a correlation analysis must be conducted on the original variables. The Kaiser-Meyer-Olkin (KMO) measure can determine whether the original variables provided using SPSS software are 
suitable for factor analysis. In this study, SPSS 22.0 is used for the Bartlett and KMO test. The results of the 12 indicators in the Bartlett's test $(\mathrm{x} 2=2506.539$; $\mathrm{p}$-value $<0.001)$ partially overlapped, and factor analysis is necessary. The KMO test is mainly designed to observe the partial correlation between the variables. The closer to 1 the statistics of the KMO test, the stronger the correlation between the variables and the better the effect of factor analysis. In the present study, $\mathrm{KMO}=0.923$; the statistics is close to 1 , and the data are suitable for factor analysis.

Table III shows that the 12 indicators can be summarized as four factors: Factor 1 (m-commerce app performance),
Factor 2 (mobile device performance), Factor 3 (service quality), and Factor 4 (user satisfaction). The eigenvalue of m-commerce app performance, mobile device performance, service quality, and user satisfaction is 4.801, 3.989, 4.183, and 1.748 , respectively. The characteristic value of every factor is greater than 1 , indicating that the number of variables that every factor explains is greater than one. Four common factors are extracted from the 12 indicators. The cumulative percentage of variance explained by four factors is $71.913 \%$, which implies that more than $72 \%$ of the common variance shared by the 12 items can be explained by these four factors. Construct validity is established.

TABLE III. FACTOR ANALYSIS

\begin{tabular}{|l|c|c|c|c|c|c|}
\hline Variable & $\begin{array}{l}\text { Scale } \\
\text { Items }\end{array}$ & & $\begin{array}{c}\text { Factor } \\
\text { loading }\end{array}$ & $a$ & $\begin{array}{c}\text { Percentage } \\
\text { of variance }\end{array}$ & Eigen values \\
\hline $\begin{array}{l}\text { M-commerce App } \\
\text { Performance }\end{array}$ & MAP1 & & 0.613 & 0.635 & 50.534 & 4.801 \\
\hline & MAP2 & & 0.671 & & & \\
\hline & MAP3 & & 0.571 & & & \\
\hline $\begin{array}{l}\text { Mobile Device } \\
\text { Performance }\end{array}$ & MDP1 & & 0.807 & 0.821 & 59.836 & 3.989 \\
\hline & MDP2 & & 0.758 & & & \\
\hline & MDP3 & & 0.765 & & & \\
\hline Service Quality & SQ1 & & 0.762 & 0.818 & 66.789 & \\
\hline & SQ2 & & 0.721 & & & \\
\hline & SQ3 & & 0.834 & & & \\
\hline User Satisfaction & US1 & & 0.691 & 0.759 & 71.913 & \\
& US2 & & 0.751 & & & \\
& US3 & & 0.703 & & & \\
\hline
\end{tabular}

\section{C.Correlation analysis}

Correlation analysis is a statistical method for the correlation between random variables. It explores whether the objects investigated are correlated as well as the trend and degree of correlation between phenomena with mutual dependence relations. In this study, Pearson's correlation coefficient is adopted to study the variables ( $\mathrm{r}=0$ : uncorrelated, $r>0$ : positive correlated, and $r<0$ : negatively correlated). The greater the absolute value of $r$, the higher the degree of correlation. The correlation analysis results of the four factors are shown in Table IV. M-commerce app performance, mobile device performance, service quality, and user satisfaction are all appreciably associated. The value of
Pearson's correlation coefficient isgreater than 0.65 , indicating an extremely high degree of correlation. The correlation coefficient between m-commerce app performance and user satisfaction is 0.728 , which is greater than that between mobile device performance (or service quality) and user satisfaction. The above results explain that certain relationships exist between the independent and dependent variables. However, the degree of relationship between every independent and dependent variable should be further tested through regression analysis. 
TABLE IV. PEARSON CORRELATION COEFFICIENT

\begin{tabular}{|l|l|l|l|l|}
\hline & $\begin{array}{c}\text { User } \\
\text { satisfacti } \\
\text { on }\end{array}$ & $\begin{array}{c}\text { M-commerce } \\
\text { App } \\
\text { performance }\end{array}$ & $\begin{array}{l}\text { Mobile } \\
\text { device } \\
\text { performance }\end{array}$ & $\begin{array}{l}\text { Service } \\
\text { quality }\end{array}$ \\
\hline User satisfaction & 1 & $0.728^{* *}$ & $0.664^{* *}$ & $0.676^{* *}$ \\
\hline M-commerce App performance & $0.728^{* *}$ & 1 & $0.606^{* *}$ & $0.672^{* *}$ \\
\hline Mobile device performance & $0.664^{* *}$ & $0.606^{* *}$ & 1 & $0.591^{* *}$ \\
\hline Service quality & $0.676^{* *}$ & $0.672^{* *}$ & $0.591^{* *}$ & 1 \\
\hline \multicolumn{2}{|l|}{ Note: **Correlation significant at the level 0.01 (two-tailed) } \\
\hline
\end{tabular}

\section{D.Multiple regression analysis}

Multivariate regression analysis is an analytical method used to measure the relationship between variables. It deepens the understanding of the qualitative analysis, obtaining the quantitative dependence between various factors and further revealing the inherent laws for the factors. The multivariate regression analysis results in this study are provided in Table V. Durbin-Watson (DW) statistic is used to test autocorrelation. As a rule of thumb, a DW statistic must range from 1.5 to 2.5 [59]. The DW value in the present study is 1.814 and is close to 2 without autocorrelation phenomena.

In multivariate regression analysis, checking whether the model has any multicollinearity is necessary. Many methods can test for multicollinearity. A commonly used method is the variance inflation factor (VIF) proposed by [60]. Normally, when $\mathrm{VIF} \geq 5$ or $\mathrm{VIF} \geq 10$, serious collinearity exists between variables. The greater the VIF value, the higher the collinearity between variables. In the present study, the VIF value of every variable is less than 5 , which indicates the absence of collinearity.

The regression coefficient for $\mathrm{m}$-commerce app performance is 0.391 , with a significance level of 0.000 (less than 0.001), indicating that the regression coefficient is significant. Thus, m-commerce app performance positively affects user satisfaction. The value for mobile device performance is 0.281 , with the significance level of 0.000 (less than 0.001), which indicates a significant regression coefficient is significant. Thus, mobile device performance positively affects user satisfaction. The value for service quality is 0.247 , with a significance level of 0.000 (less than 0.001 ), which indicates that the regression coefficient is significant. Thus, service quality positively affects user satisfaction. M-commerce app performance, mobile device performance, and service quality positively affect user satisfaction, and $\mathrm{H} 1, \mathrm{H} 2$, and $\mathrm{H} 3$ are valid.

TABLE V. MULTIPLE REGRESSION ANALYSIS

\begin{tabular}{|c|c|c|c|c|c|}
\hline Predictor variable & $\beta$ & $\begin{array}{c}t- \\
\text { value }\end{array}$ & Sig & Tolerance & VIF \\
\hline $\begin{array}{ll}\text { M-commerce } & \text { App } \\
\text { performance } & \end{array}$ & 0.391 & 9.293 & 0.000 & 0.481 & 2.079 \\
\hline Mobile device performance & 0.281 & 7.291 & 0.000 & 0.572 & 1.750 \\
\hline Service quality & 0.247 & 5.966 & 0.000 & 0.495 & 2.020 \\
\hline
\end{tabular}

test $=1.814$

\section{VII.DISCUSSION AND CONCLUSION}

M-commerce app performance exerts positive effects on user satisfaction. The literature states that $\mathrm{m}$-commerce app performance influences user satisfaction $[42,43]$. The present study further supports these conclusions and proves that $\mathrm{m}$ commerce app performance positively affects user satisfaction. Studies have shown that the displayed contents of mobile apps are limited by the screen sizes of mobile devices. Apps with aesthetic design [22], convenient navigation, and rich contents are attractive, increasing user intention-to-use. M-commerce apps require improved balance between interaction design and ease of operation. They focus on introducing popular elements to attract young users, further optimizing performances of m-commerce apps, reducing unnecessary links related to user personal information, strengthening privacy protection, and enhancing user satisfaction.

Mobile device performance positively affects user satisfaction. The conclusions are consistent with those of previous studies $[22,35,39]$. The portability of mobile devices is a key factor attracting user adoption of mcommerce. The information/data processing speeds of mobile devices contribute greatly to user satisfaction. The screen 
sizes of mobile devices considerably affect the content display of m-commerce. Mobile devices with larger screens can enhance user satisfaction toward m-commerce. Considering user demands, mobile device manufacturers should design ergonomic mobile devices [35], cooperate with m-commerce app developers, design individualized mobile intelligent terminals, and enhance user satisfaction.

The service quality of $\mathrm{m}$-commerce positively affects user satisfaction. This finding is similar to the those of previous studies [40, 57]. M-commerce users should provide timely feedback and difficulties and enhance user satisfaction. Mcommerce participants should resolve problems and difficulties for users in a timely fashion through mobile social networking media, e-mail, and other channels, enhance the efficiency of logistics and distribution services, provide users with high-quality and real-time logistic information services

\section{VIII.LIMITATION AND FUTURE STUDIES}

Mobile communication technologies, smartphones, and other mobile terminals have laid a solid foundation for the development of m-commerce. With the increasing number of mobile terminal users and technological changes in $\mathrm{m}$ commerce, various innovative e-commerce services have been introduced. At present, the applications of $\mathrm{m}$-commerce have covered all aspects of entertainment, finance, trade, management, marketing, tourism, education, and daily life. Therefore, while paying attention to mobile information services, mobile payment, and mobile shopping, factors influencing user satisfaction toward novel m-commerce services should be comprehensively investigated.

In terms of the selection of factors affecting user satisfaction, most studies start from perceived usefulness, perceived ease-of-use, and security. This study focuses only on several aspects of these three factors, without comprehensively considering perspectives from individual, organizational, and national levels. Enhancing user satisfaction requires system engineering. The influencing factors not only cover the microscopic level but also organizational, industrial, and macro-levels. Studying the factors influencing the adoption of $\mathrm{m}$-commerce only from social psychology and common user perspectives is one-sided. Establishing a new theoretical framework that considers all influencing factors at individual, organizational, and national levels is necessary.

Given the varying economic development, information infrastructure, laws and regulations, and culture of countries,

\section{REFERENCES}

[1] R. J.-H. Wang, E. C.Malthouse, and L. Krishnamurthi, "On the Go: How mobile shopping affects customer purchase behavior,"Journal of Retailing,vol.91,no.(2),pp.217-234,2015.

[2] T.T.Wei, G.Marthandan, A.Y.L.Chong, K.B.Ooi, and S.Arumugam, "What drives Malaysian m-commerce adoption An empirical analysis,"Industrial Management \& Data Systems,vol.109,no.(2),pp.370$388,2009$.

[3] Q.Min, S.B.Ji, and G.Qu, "Mobile commerce user acceptance study in china:a revised UTAUT model,"Tsinghua science \& and timely distribution and delivery services for physical goods, and enhance user satisfaction.

To enhance the user satisfaction, all participants of the mcommerce ecosystem should strengthen cooperation, objectively analyze user consumption behavior, optimize the structural layout and navigation design of m-commerce website, simplify user operations, and enhance user satisfaction app performance. They should improve user experience, improve the performance and design of mobile devices, and increase user satisfaction with mobile device performance. They must increase the speed and efficiency of user feedback, improve user satisfaction with the service quality of m-commerce, provide full playing opportunities to the roles of participants of the m-commerce ecosystem, and enhance user satisfaction toward m-commerce.

the development of m-commerce is unbalanced at national level. The factors influencing user satisfaction also differ. At present, studies related to user satisfaction are mainly concentrated on economically developed countries where mobile Internet access is extremely popular, such as Europe, America, Korea, Japan, and Taiwan. By contrast, few studies have been conducted in underdeveloped countries with low popularity of mobile Internet. User satisfaction should be further studied from national and regional perspectives.

An empirical study on the factors influencing user satisfaction is conducted from a micro-level perspective. Despite the several research conclusions provided in this study, respondents are limited to college students. Although the current users of m-commerce are mainly young users, users who come from other places with different living habits and income are overlooked. In future studies, the scope of investigation must be widened to include different user groups. Comparative studies on users with different cultural backgrounds may also be conducted.

\section{ACKNOWLEDGMENT}

This study was supported by the China Scholarship Council (201408420159) and Humanities and Social Science research project in Hubei province department of education (13g587 and 114Z073).

Technology,vol.13,no.(6),pp.257-264,2008.

[4] C. E.-B. r. Center, China mobile electric business market annual reporet 2015-2016, 2016.

[5] S. J.Barnes, "The mobile commerce value chain: analysis and future developments,"international Journal of Information Management,vol.22,no.(1),pp.91-108,2002.

[6] R. Strom, M. Vendel, and J. Bredican, "Mobile marketing: A literature review on its value for customers and retailers,"Journal of Retailing and concumer service,vol.21,no.(2),pp.1001-1012,2014.

[7] F. Buellingen, and M. Woerter, "Development perspectives,firm strategies and applications in mobile commerce,"Journal of Business Research,vol.57,no.(1),pp.1402-1408,2004. 
[8] E. W. T. Ngai, and A. Gunasekaran, "A review for mobile commerce research and applications,"Decision Support Systems,vol.43,no.(1),pp.315,2007 .

[9] S. Gurtner, R. Reinhardt, and K. Soyez, "Designing mobile business applications for different age groups,"Technological Forecasting \& Social Change,vol.88,no.(6),pp.177-188,2014.

[10] A. Y.-L. Chong, "Mobile commerce usage activities: The roles of demographic and motivation variables,"Technological Forecasting \& Social Change,vol.80,no.(1),pp.1350-1359,2013.

[11] K. C. C. Yang, "Exploring factors affecting the adoption of mobile commerce in Singapore,"Telematics and Informatics,vol.22,no.(1),pp.257277,2005 .

[12] A. Y.-1. Chong, "Predicting m-commerce adoption determinants: A neural network approach,"Expert Systems with Applications,vol.40,no.(2),pp.523-530,2013.

[13] A. Y.-L. Chong, "A two-staged SEM-neural network approach for understanding and predicting the determinants of m-commerce adoption,"Expert Systems with Applications,vol.40,no.(6),pp.12401247,2012 .

[14] A. Y.-L. Chong, "Understanding mobile commerce continuance intentions: An empirical analysis of chinese consumers,"Journal of Computer Information Systems,vol.53,no.(4),pp.22-30,2013.

[15] S. Agrebi, and J. Jallais, "Explain the intention to use smartphones for mobile shopping,"Journal of Retailing and concumer service,vol.22,no.(1),pp.16-23,2015.

[16] K. M.s.Faqih, and M.-I. r. m. jaradat, "assessing the moderating effect of gender differences and individualism-collectivism at individual-level on the adoption of mobile commerce technology:TAM3 perspective,"Journal of Retailing and concumer service,vol.22,no.(1),pp.37-52,2015.

[17] K. Yang, "Consumer technology traits in determining mobile shopping adoption: An applicaiton of the extended theory of planned behavior,"Journal of Retailing and concumer service,vol.19,no.(2),pp.484$491,2012$.

[18] D. Gefen, E. Karahanna, and D. W. Straub, "Trust and TAM in online shopping: An intergrated model,"MIS Quarterly,vol.27,no.(1),pp.5190,2003.

[19] P. A. Pavlou, "Consumer acceptance of electronic commerceintegrating trust and risk with the technology acceptance model,"International Journal of Electronic Commerce,vol.17,no.(3),pp.101$134,2003$.

[20] M. Nilashi, O. Ibrahim, V. R. Mirabi, and L. Ebrahimi, "The role of security ,Design and content factors on customer trust in mobile commerce,"Journal of Retailing and concumer service,vol.26,no.(3),pp.57$69,2015$.

[21] Y.-M. Li, and Y.-S. Yeh, "Increasing trust in mobile commerce through design aesthetics,"computer in Human Behavior,vol.26,no.(2),pp.673-684,2010.

[22] D. Cyr, M. Head, and A. Ivanov, "Design aesthetics leading to mloyalty in mobile commerce,"Informatin \& management,vol.43,no.(6),pp.950-963,2006.

[23] J. Lin, Y. Lu, B. Wang, and K. k. Wei, "The role of inter-channel trust transfer in establishing mobile commerce trust,"Electronic commerce research and applications,vol.10,no.(4),pp.615-625,2011.

[24] S. San-Martin, and B. Lopez-catalan, "How can a mobile vendor get satisfied customers,"Industrial Management \& Data Systems,vol.113,no.(2),pp.156-170,2013.

[25] J. Jamaluddin, Z. N, E. R, and C. P, "Mobile phone vulnerabilities: A new generation of malware."

[26] H. Xu, "The effect of perceived security on consumers' intent to use: satisfaction and loyalty to M-commerce in china,"Journal of electronic Commerce in organization,vol.11,no.(4),pp.37-51,2013.

[27] S. San-Martin, J. Prodanova, and N. Jimenez, "The impact of age in the generation of satisfaction and WOM in m obile shopping,"Journal of Retailing and concumer service,vol.23,no.(1),pp.1-8,2015.

[28] H.-H. Lin, and Y.-S. Wang, "An examination of the determinants of customer loyalty in mobile commerce contexts,"Informatin \& management,vol.43,no.(1),pp.271-282,2006.

[29] R.L.Oliver, "whence consumer loyalty,"Journal of Marketing,vol.63,no.(special issue), 1999.

[30] J. Lu, "Are personal innovativeness and social influence critical to continue with mobile commerce,"Internet Research,vol.24,no.(2),pp.134$159,2014$.

[31] J. Choi, H. Seol, S. lee, H. Cho, and Y. Park, "Customer satisfaction factors of mobile commerce in Korea,"Internet Research,vol.18,no.(3),pp.313-335,2008.

[32] H. Kim, J. Kim, and Y. Lee, "An empirical study of use context in the mobile internet,focusing on the usability of information architecture,"Information systems frontiers,vol.7,no.(2),pp.175-186,2005.

[33] J. Cheong, and M. Park, "Mobile Internet acceptance in Korea,"Internet Research,vol.15,no.(2),pp.125-140,2005.

[34] J. Wu, and S. Wang, "What drices mobile commerce?An empirical study evaluation of the revised technology acceptance model,"Information \& Management,vol.42,no.(5),pp.719-729,2005.

[35] S. Okazaki, and F. Mendz, "Exploring convenience in mobile commerce: Moderating effects of gender,"Computers in Human Behavior,vol.2013,no.(1),pp.1234-1242,2013.

[36] Y. S. Yeh, and Y.-M. Li, "Building trust in m-commerce: contribution from quality and satisfaction,"Online information review,vol.33,no.(6),pp.1066-1086,2009.

[37] W.-T. Wang, and H.-M. Li, "Factors influencing mobiel services adoption:a brand-equity

Research,vol.22,no.(2),pp.142-179,2012.

[38] N. M. Suki, "A structural model of customer satisfaction and trust in vendors involved in mobile commerce,"Journal of business science and applied management,vol.6,no.(2),pp.17-30,2011.

[39] A. Sonderrgger, and J. Sauer, "The influence of design aesthetics in usability testing: effects on user performance and perceived usability,"Applied Ergonomics,vol.41,no.(1),pp.403-410,2010.

[40] T. Zhou, "Examining the critical success factors of mobile website adoption,"Online information review,vol.35,no.(4),pp.636-652,2011.

[41] L. Zhang, J. Zhu, and Q. Liu, "A mata-analysis of mobile commerce adoption and the moderting effect of culture,"Computer in Human Behavior,vol.28,no.(6),pp.1902-1911,2012.

[42] Y.-S. Wang, and Y.-W. Liao, "The conceptualization and measurement of m-commerce user satisfaction,"Computers in Human Behavior,vol.23,no.(1),pp.381-398,2007.

[43] C. Flavian, M. Guinaliu, and R. Gurrea, "The role played by perceived usability,satisfaction and consumer trust on website loyalty,"Informatin \& management,vol.43,no.(1),pp.1-14,2006.

[44] J. Song, J. Kim, D. R.Jones, J. Baker, and W. W. Chin, "Application discoverability and user satisfaction in mobile application stores:An environmental psychology perspective,"Decision Support Systems,vol.59,no.(1),pp.37-51,2014.

[45] Wong, and S. H. Rebekah, "which platform do our users prefer: website or mobile app?,"Reference service review,vol.40,no.(1),pp.103115,2012 .

[46] S. M.Dye, and K. Scarfone, "A standard for developing secure mobile applications,"Computer standards \& Interfaces,vol.36,no.(1),pp.524$530,2014$.

[47] G. C.-C. Shen, "Users adoption of mobile applications:Product type and message framings moderating effect,"Journal of Business Research,vol.68,no.(4),pp.2317-2321,2015.

[48] D. Robins, and J. Holmes, "Aesthetics and credibility in web site design,"Information procesing and management,vol.44,no.(1),pp.386399,2008.

[49] J.-Y. M.Kang, J. M. Mun, and K. K.P.Johnson, "In-store mobile usage: Downloading and usage intention toward mobile location-based retail apps,"Computer in Human Behavior,vol.46,no.(2),pp.210-217,2015.

[50] M. A. Rababaa, M. A. Kofahi, and M. A. Ai-Saqqar, "Hash algorithms for security on GSM system,"International Review on computers \& software,vol.4,no.(6),pp.698-703,2009.

[51] H.-P. Lu, and P. Y.-J. Su, "Factors affecting purchase intention on mobile shopping web sites,"Internet Research,vol.19,no.(4),pp.442458,2009 .

[52] Y. F. Chang, C. S. Chen, and H. Zhou, "Smart phone for mobile commerce,"Computer standards \& Interfaces,vol.31,no.(1),pp.740$747,2009$.

[53] D. Lee, J. Moon, Y. J. Kim, and M. Y.Yi, "Antecedents and consequences of mobile phone usability:linking simplicity and interactivity to satisfaction,trust and brand loyalty,"Informatin \& 
management,vol.52,no.(1),pp.295-304,2015.

[54] J. Veijalainen, V. Terziyan, and H. Tirri, "Transaction management for m-commerce at a mobile terminal,"Electronic commerce research and applications,vol.5,no.(6),pp.229-245,2006.

[55] T. Zhou, Y. Lu, and J. Zhang, "A study on accptance behavior of mobile commerce user based on perceived value and trust,"Chinese Journal of Management,vol.6,no.(10),pp.1407-1412,2009.

[56] J.-H. Wu, and S.-C. Wang, "What drives mobile commerce? An empirical evaluation of the revised technology acceptance model,"Informatin management,vol.42,no.(1),pp.719-729,2005.
[57] G. Buyukozkan, "Determining the mobile commerce user requirements using an analytic approach,"Computer standards \& Interfaces,vol.31,pp.144-152,2009.

[58] Nunnally.J, Psychometric Theory, New York,NY, 1978

[59] K. B. Ooi, V. Arumugam, P. L. Teh, and A. Y. L. Chong, "TQM practice and its association with production workers,"Industrial Management \& Data Systems,vol.108,no.(7),pp.909-927,2008.

[60] S. Chatterjee, and B. Price, Regression analysis by example, p.^pp. 186-197, New York: Wiley, 1991. 